Titel:

Outeur:

Nomadiese sterre

Uitgewer:

Joan Hambidge

ISBN:

Protea Boekhuis, Pretoria

978-1-4853-1263-5

\title{
"In die gebreekte spieël van die self”: skryf en die psige in Hambidge se jongste bundel
}

Joan Hambidge se jongste bundel, Nomadiese sterre (2021), het vroeër vanjaar by Protea Boekhuis verskyn. Die titel van die bundel is ontleen aan die gedig "Onder nomadiese sterre" (11) en kan gesien word as 'n soort voorwoord of sleutel tot die ontsluiting van die tematiek wat in die bundel aangespreek word.

In die notas agterin, vermeld Hambidge dat die titel inspeel op Ernst van Heerden se gedig "Bosveldse plaas" geneem uit Kanse op 'n wrak (Tafelberg: 1982). In Hambidge se gedig word die skryfdaad as poging tot reparasie van die psige voorgestel:

Van kleins af eenspaaiig, eenrymend,

stilte beleef, met sinne ópgeskerp:

suurlemoene op 'n bitter tong geproe.

Eerste woorde op 'n lei gekrabbel

en vandaar tot skryf- en kladboek beweeg

waar woorde vlerke klap: lysters op dor gras.

Ligusterbosse, akante, jakarandas gloei

in hierdie vlymende onthouboeke.

In die gebreekte spieël van die self

(iewers verbeeld tot poësie)

oorgange en rituele in reliëf berym.

Hierin staan twee dinge voorop: die skryfdaad en die psige. Die fokus op die skryfdaad word beklemtoon deur die opdrag voorin, opgedra aan Ina Gräbe en Johann de Lange; eersgenoemde wat Hambidge uitsonder as "voorste kenner van poëtiese taal".

Die "self" as psigoanalitiese begrip, wat veral weerklank vind in die literatuurwetenskap, is dan ook 'n kenmerk van Hambidge se digterskap, waarin sy die literatuurwetenskap en die poësie op 'n kritiese en kreatiewe wyse integreer. Laasgenoemde is een van die redes waarom ek Hambidge as een van ons groot Afrikaanse digters ag.

Die bundel bestaan uit sewe afdelings en word ingelui deur twee motto's. Die eerste is deur die vooraanstaande Amerikaanse modernis Marianne Moore: "The cure for loneliness is solitude"; die tweede, deur Theodore Roethke: "I live near the abyss. I hope to stay/ Until my eyes look at a brighter sun/ As the thick of the long night comes on".

Carl Jung (1875-1961) is een van die mees prominente psigoanaliste. Hambidge maak gebruik van sy outobiografie, getiteld Memories, Dreams, Reflections (1961), en buikspreek 'n brief wat hy aan sy vrou, Emma, skryf. Hierin vertel Jung van sy reise deur Afrika, en begin deur te vertel hoe hy "ongelukkig nie/ sober of sinvol" aan haar kan skryf nie; hy vermeld 'n aantal gebeure, wat 'n klimaks bereik in hoe hulle “op 'n treinreis [...]/ per ongeluk 'n kameel raakgery [het]" en dat daar "in die nag [...] onheilspellende/ wit figure" verskyn het "om te red wat on-redde is". Teen die einde van die gedig, asof nagepraat deur die digter self, sê Jung: 
Ek weet nie wat Afrika vir my sê nie, maar dit práát...

Dit is dan juis in navolging van die begeerte om te hoor wat gesê word dat Jung tot skrywe gedwing word. Is dit eweneens die geval met Hambidge? Om terug te keer na die openingsvers - vergelyk: "Telkens 'n self verloor, soos 'n slang/ vervel in die klein rondeau of villanelle/ van 'n lewe vol sonsverduistering". Let op Hambidge se uitstekende metaforiese taalgebruik, wat simbolies gelees kan word as 'n proses van individualisering.

In afdeling twee leun Hambidge weer terug na die skrywe self. In die eerste drie gedigte word spesifiek gesinspeel op die werk van NP van Wyk Louw: In "Hierdie is nie 'n liefdesvers nie" (17) word ons voorgestel aan "'n X/ wat geen silwer herberg bewoon/ in die sneeu nie, maar ewigdurend/ sous rature bly". Let op die Derridiaanse spel, van die geliefde "onder uitwissing" ("sous rature") plaas, 'n spel met die aanwesige afwesige. Die gedig speel dan ook terug na Van Wyk Louw as vaderfiguur, wat onder uitwissing geplaas word deur die gedig te parodieer, maar terselfdertyd hierdeur gehuldig word. Hambidge borduur verder op gedigte uit Tristia (1962) voort in "Ignatia bid vir haar orde" (18) en "Cartesiaan" (19). Vir dié lesing is dit veral laasgenoemde wat uitstaan. Hierin word "Freud en Lacan - die gode van drieë" benoem in teenstelling met die dualistiese denke van René Descartes: "Hulle dink aan skakels: aan oorgange/ soos ego, id, superego, nes bedrieë:/ verbeelde, simboliese, reële vir dié drange".

Soos die tyd bepaal, ontgin Hambidge veral dan ook ervarings van die Covid-19-pandemie as gedigte. In "Ars poetica" (23) word die gedig eksemplaries as "stil getuie" bedink "van tye wat nooit verby sal gaan".

In "Antigone" (33) uit afdeling drie word die spreker 'n buikspreker van haar ouers: "My naam bedui in die plek van my ouers". So word narratiewe opgeteken oor die verhouding met hulle, byvoorbeeld "Vakansie, 1969" (36) in Gordonsbaai. "Brief van my pa" (46) en "Brief van my ma" (47) is dan daardie "buikspreekgedigte", waarin die digtersfiguur haar ouers se briewe naskryf. Uit die eerste:

"Ek is altyd so bly om jou stem te hoor.

So trots op jou en bid elke dag vir ons almal.

Kyk na Beeld se kalender van 2 Maart 1995."

Gelees weer op Maandag 29 Junie 2020, wonder ek hóé jou gebede nou sou klink in hierdie tyd van 'n virale oorlog onbeklink?

Afdeling vier behels 'n aantal lykdigte soos kenmerklik van Hambidge se poëtiese oeuvre, waarvan "Sweisbril: Jaco Botha (1972-2016)" (54) 'n hoogtepunt is. Hierin verbeeld sy Botha, wat met slegs $10 \%$ sig gebore is, as "daardie man met die sweisbril,/ wat inkyk tot by die Onsienlike verby"; in "Gisela Ullyatt (1977-2020)" (58) word melding gemaak van haar "eerste en laaste bundel" - Die waarheid oor duiwe (2020) - en "die vibracrete-dae van jou jeug", met spesifieke verwysing na Ullyatt se openingsgedig in haar bundel.

In "Ars poetica II" (67) verwys die spreker na 'n gedagte van die Amerikaanse digter Wallace Stevens, naamlik dat poësie geweld is. Hierdie gedig verwys self terug na die gedig met die titel "Wallace Stevens" (66). Die spreker vermeld dat Stevens se "sonderlinge staproete" nou te vinde is op die internet. (In die notas agterin word selfs die webadres van die Wallace Stevens-staproete weergegee.) Op Stevens se lessenaar is die volgende aforisme te lees: "Not Ideas about the Thing but the Thing Itself"; ook: "In 'n kladboek staan daar neergekrabbel:/ Poetry represents failure". Hierdie aforismes werk die digter as 'n soort metapoëtika by die 
gedigte in - vergelyk later in dieselfde gedig: "My blouversameling met jou gedigte/ dra my deur hierdie virale dae:/ The cry is part. My solitaria/ Are the meditations of a central mind./ I hear the motions of the spirit and the sound".

In navolging van Johan Myburg se gedig "Prosopopeia" in Uittogboek (2017), bemaak Hambidge 'n gedig aan Myburg met dieselfde titel: "By al die meesters/ van die onsigbare bedryf/ staan dit opgeteken/ dat jy moet buikspreek" (68). Hierin staan die betekenis van "prosopopeia" as 'n stylfiguur voorop, waarin 'n verbeelde, afwesige of dooie persoon of ding voorgestel word om te praat.

Breyten Breytenbach word in die sesde afdeling van die bundel vereer met 'n gedig getiteld "Die ongedanste dans" (73-75). Die titel verwys na Breytenbach se gevangenisgedigte. Hambidge se gedigsiklus bestaan uit drie verse, waarvan die eerste as ' $n$ loflied aan die digter gelees kan word: "O ek onthou die eerste dans met jou verse/ O ek begeer 'n vers uit jou windvangerharp". Hierdie gedig is 'n "paradelle", wat beskryf word as 'n parodie van die villanelle.

Afdeling sewe bestaan slegs uit een gedigsiklus, getiteld "Witbank-blues" (77-81), bestaande uit tien verse. Hierin word vele herinneringe aan die spreker se jeug vol musiek en nuuskierige gewaarwordinge opgeteken. Dit is veral die eensaamheid van die moeder wat die leser in hierdie gedig met 'n melancholiese gemoed laat:

Ma speel klavier, ons doen huiswerk en saans praat $\mathrm{Pa}$ oor sy lang ure by Ou Mutual, terwyl die baba eentonig begin hoes.

Ma verlang na die blou-blou berge van die Boland weg van die mynhope, besoedeling, beproewinge van kinders grootmaak en afbetaal aan 'n huisverband en 'n bestaan tussen melkkoepons en kleremaak. 'O blou-blou berge van die Boland,' sing sy vanaand, verlangend asof in 'n vreemde land.

Op die laaste bladsy van die bundel vind mens 'n astrologiese kaart van Joan Hambidge. Terugkerend beskou sou mens kon dink dat Nomadiese sterre gelees kan word as 'n boek van dit wat vooraf reeds in sterre geskryf is asof voorbestem. 'n Bundel met grootse oomblikke, wat die self in kaart bring en binne 'n groter prentjie uitkring, van familie, vriende, skrywers, kollegas, asook die pandemie, wat die gordyn wil-wil toetrek oor 'n ou wêreld in die aangesig van 'n onsekere nuwe wêreld. Dit alles onder nomadiese sterre, wat eweneens die vraag probeer beantwoord: "Waar is hulle wat voor ons was in die wêreld?".

\section{Alwyn Roux}

Departement Afrikaans en Algemene Literatuurwetenskap

UNISA

E-pos: erouxap@unisa.ac.za 